\title{
Classification of the meridionally costellate Cretaceous planktonic foraminifera
}

\author{
HAMED A. EL-NAKHAL \\ Department of Environment and Earth Science, Faculty of Science, The Islamic University of Gaza, PO Box 108, Gaza, Palestine (via Israel).
}

\begin{abstract}
The meridionally arranged rugosity, which is restricted to the Cretaceous globigerines, is given a superfamily taxonomic status. The globigerines displaying this type of ornamentation are placed in the Rugoglobigerinacea which is subdivided into two families the Rugoglobigerinidae and the Abathomphalidae. The Rugoglobigerinidae includes the forms having an umbilical primary aperture with a tegillum (Rugoglobigerina Brönnimann, Trinitella Brönnimann, and Plummerita Brönnimann). The Abathomphalidae includes the genera which have an umbilical-extraumbilical to spiro-umbilical primary aperture with a tegillum (Abathomphalus Bolli, Loeblich \& Tappan, and Kassabella El-Nakhal), or a porticus (Meridionalla El-Nakhal, and Badriella n. gen.). Badriella is introduced as a new genus with $B$. mouradi n. sp. (= hypotype of Praeglobotruncana loeblichae Douglas) as a type species, to accommodate the meridionally costellate species with compressed chambers and umbilical-extraumbilical primary aperture, which were previously assigned to Praeglobotruncana Bermudez. The Rugoglobigerinacea may have evolved from a hedbergelline ancestor during the latest Albian via the development of the meridinally arranged rugosity. J. Micropalaeontol. 21(1): 1-8, May 2002.
\end{abstract}

\section{INTRODUCTION}

The Cretaceous planktonic foraminifers include several forms which display a peculiar ornamentation pattern in the form of meridionally aligned costellae. Saint-Marc (1973), Caron (1978) and Caron \& Homewood (1982/1983) believed that this type of textural ornamentation was developed in response to environmental factors. Pessagno (1967), Blow (1979), Petters et al. (1983) and Belford (1983) regarded it as a genetically controlled character. This type of ornamentation is displayed by a particular group of globigerines, which are restricted to the Cretaceous and never seen before or after that period. Taxa with, and without, meridional costellae occur together (for example in Kuwait, El-Nakhal, 1973, and in Western Australia, Belford, 1983), and the view that development of these costellae is genetically controlled seems to be reasonable and, therefore, is here accepted and the character considered as an important taxonomic feature.

The taxonomic significance of meridional ornamentation has received different interpretations. Olsson (1964) and Kassab (1976) considered it to be of specific importance, whereas Brönnimann (1952), El-Nakhal (1982, 1984), Petters et al. (1983) and Belford (1983) assign it a generic importance. Pessagno (1967) and Longoria \& Gamper $(1975,1984)$ regarded the presence of unique types of ornamentation, like meridional rugosities or polygonal areas (honeycomb ornamentation), as a family character. Due to its taxonomic importance, and to facilitate the clasification of the related genera, the meridionally aligned rugosity is here given a superfamily status. It is suggested, therefore, that all the globigerines which have meridionally aligned costellae are placed in one taxon of superfamily rank; that is the Rugoglobigerinacea Subbotina, 1959. Furthermore, on the basis of the apertural characteristics of the included genera, this superfamily is subdivided into two families: the Rugoglobigerinidae Subbotina, 1959, and the Abathomphalidae Pessagno, 1967, to include the genera with umbilical, and umbilical-extraumblical to spiro-umbilical primary apertures, respectively (Table 1).

\section{SYSTEMATICS}

The classification followed in the present study is that of Loeblich \& Tappan (1988).

Order Foraminiferida Eichwald, 1830

Suborder Globigerinina Délage \& Herouard, 1896

Superfamily Rugoglobigerinacea Subbotina, 1959

(in Rauzer-Chernusova \& Fursenko, 1959)

1959 Rugoglobigerininae Subbotina; in Rauzer-Chernousova \& Fursenko: 303.

Superfamily Rugoglobigerinacea

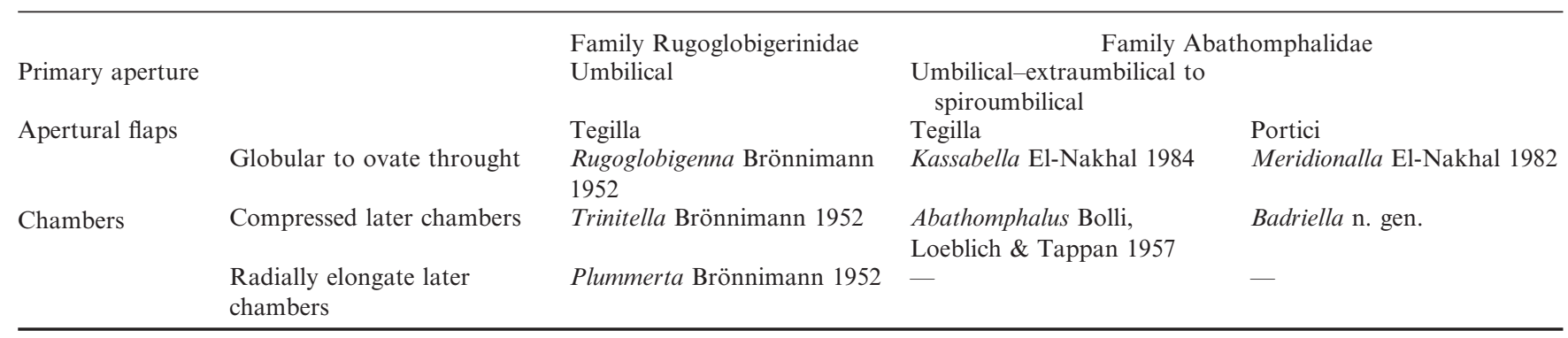

Table 1. Classification of the superfamily Rugoglobigerinacea Subbotina, 1959 


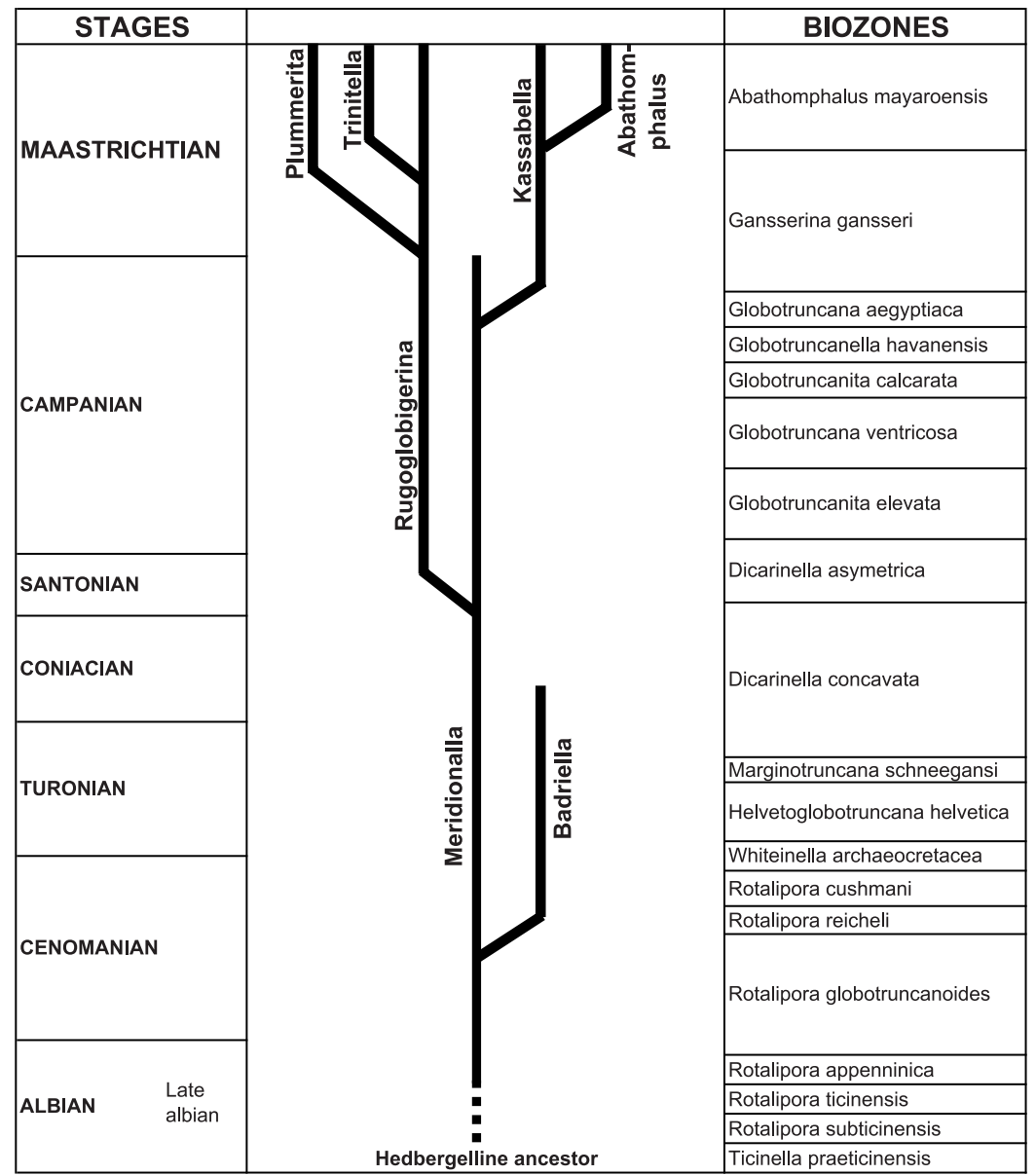

Fig. 1. Suggested phylogeny and stratigraphical ranges of the members of the Ruglobigerinacea at the generic level; biozones after Robaszynski \& Caron (1995).

1982 Rugoglobigerinidae Loeblich \& Tappan : 34.

1988 Rugoglobigerinidae Loeblich \& Tappan : 471.

Diagnosis. Globigerinina with meridionally costellate ornamentation.

Emended description. Test trochospirally enrolled, chambers globular, radially elongate, or angular and may have peripheral imperforate carinal band; wall calcareous, perforate, surface with pustules, rugosites, and costellae in a meridional pattern; primary aperture, umbilical, umbilical-extraumbilical to spiroumbilical, bordered by a porticus or covered by tegilla.

Range. Latest Albian-Maastrichtian (Fig. 1).

Family Rugoglobigerinidae Subbotina

(in Rauzer-Chernousova \& Fursenko, 1959)

1959 Rugoglobigerininae Subbotina; in Rauzer-Chernousova \& Fursenko: 303

1982 Rugoglobigerinadae Loeblich \& Tappan: 34.

1988 Rugoglobigerinadae Loeblich \& Tappan: 471.

Diagnosis. Rugoglobigerinacea with umbilical primary aperture and tegilla.

Emended description. Test trochospirally enrolled, chambers globular, radially elongate, or angular and may have peripheral imperforate carinal band; wall calcareous, perforate, surface with pustules, rugosities and costellae in a meridional pattern; primary aperture umbilical covered with tegilla.

Range. Early Santonian-Maastrichtian.

Genus Rugoglobigerina Brönnimann, 1952

(Pl. 1, figs 1-4)

1952 Rugoglobigerina Brönnimann: 16.

Type species. Globigerina rugosa Plummer, 1927, p. 38.

Diagnosis. Rugoglobigerinidae with globular chambers throughout.

Description. Test in low to flat trochospiral coil of rapidly enlarging globular chambers, biconvex, umbilicate, umbilicus wide, axial periphery rounded, equatorial periphery lobulate, non-carinate, sutures radial to slightly curved on spiral side, radial on umbilical side, depressed throughout; wall calcareous, perforate, surface with pustules, rugosities and costellae in a meridional pattern; primary aperture interiomarginal, umbilical with tegilla and proximal and distal accessory apertures.

Range. Early Santonian-Maastrichtian. 


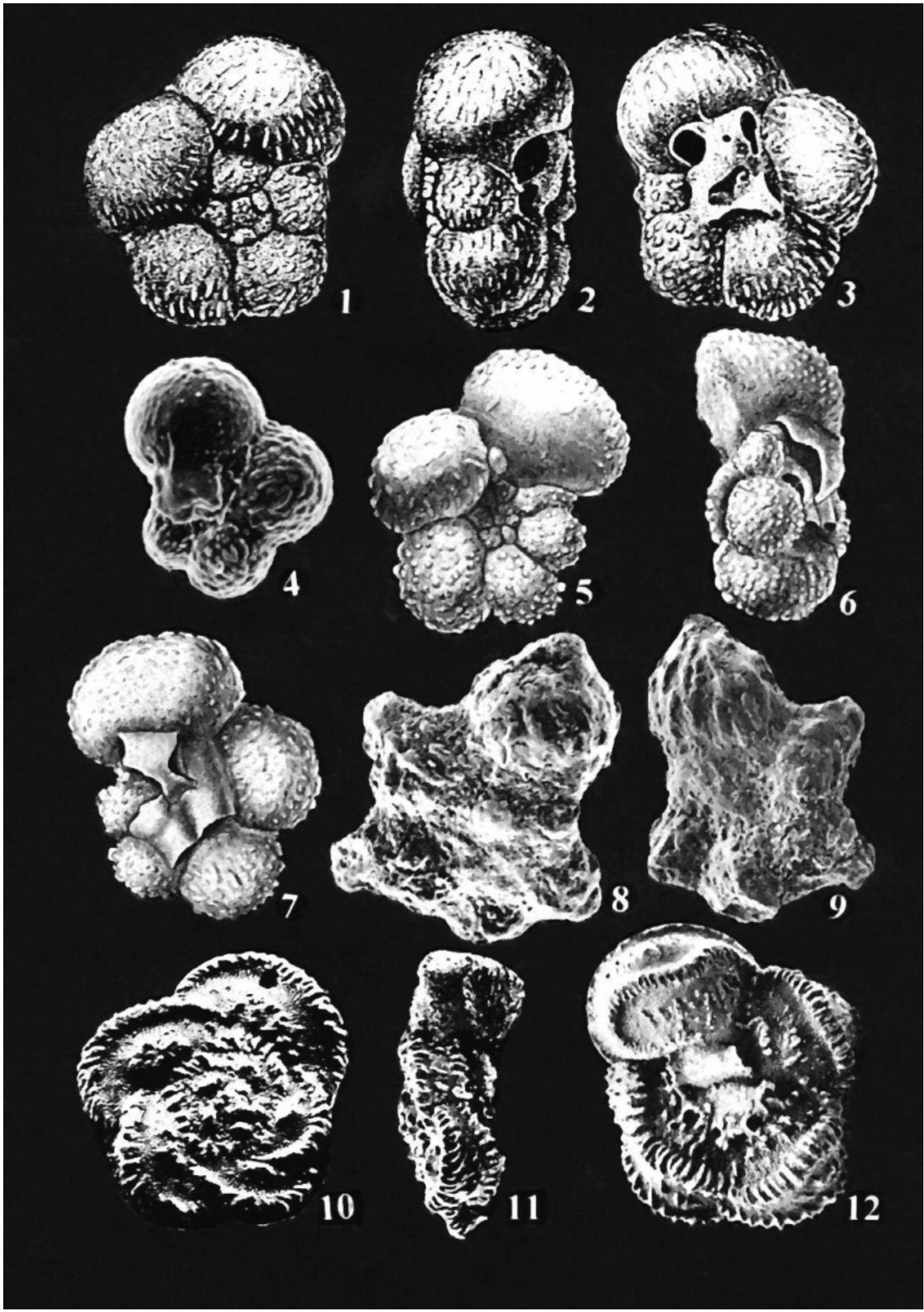

Explanation of Plate 1

Figs 1-3. Rugoglobigerina rugosa (Plummer), Maastrichtian, Texas, USA, × 135 (from Loeblich \& Tappan, 1964): 1, spiral view; 2, edge view; 3, umbilical view. Fig. 4. Rugoglobigerina macrocephala Brönnimann, middle Maastrichtian, Kuwait, $\times 175$, umbilical view (from El-Nakhal, 1973 and El-Nakhal \& El-Naggar, 1983/1984). Figs 5-7. Trinitella scotti Brönnimann, Maastrichtian, Texas, USA, × 150 (from Loeblich \& Tappan, 1964): 5, spiral view; 6, edge view; 7, umbilical view. Figs 8, 9. Plummerita hantkeninoides costata (Brönnimann), upper Maastrichtian, northern Tunisia: 8, spiral view $\times 320 ; 9$, umbilical view $\times 305$ (from Salaj \& Solakius, 1984). Figs 10-12. Abathomphalus mayaroensis (Bolli), Maastrichtian, Rio Grande Rise, southern Atlantic Ocean (from Saito \& Van Donk, 1974): 10, spiral view $\times 75$; 11, edge view $\times 60$; 12, umbilical view $\times 75$. 
Genus Trinitella Brönnimann, 1952

(Pl. 1, figs 5-7)

1952 Trinitella Brönnimann: 56

Type species. T. scotti Brönnimann, 1952, p. 56.

Diagnosis. Rugoglobigerinidae with compressed later chambers.

Description. Test in flat trochospiral coil, chambers enlarging rapidly as added, early ones globular, later chambers compressed to rhomboidal in section, with imperforate carinal band or faint keel in the final whorl, umbilicate, umbilicus wide, sutures radial, depressed, axial periphery rounded, subangular to truncate, equatorial periphery lobulate; wall calcareous, perforate, surface covered with prominent pustules and costellae in meridional arrangement, less prominent on the final chamber; primary aperture interiomarginal, umbilical, bordered by an imperforate flap, those of successive chambers fusing into tegillum having both proximal and distal accessory apertures.

Range. Middle and Late Maastrichtian.

Genus Plummerita Brönnimann, 1952

(Pl. 1, figs 8, 9)

1952 Rugoglobigerina (Plummerella) Brönnimann: 37 1942 non de Long.

Type species. Rugoglobigenna (Plummerella) hantkeninoides hantkeninoides Brönnimann, 1952, p. 37.

Diagnosis. Rugoglobigerinidae with radially elongate later chambers.

Description. Test with inflated triangular chambers in a low trochospire, those of the final whorl radially elongate and ending in a tubulospine, sutures radial, depressed umbilicus small, axial periphery rounded to compressed between tubulospines, equatorial periphery strongly lobulate and stellate; wall calcareous, perforate, surface with rugosities and costellae in meridional alignment; primary aperture interiomarginal, umbili$\mathrm{cal}$, provided with tegilla, and having both proximal and distal accessory apertures.

Range. Maastrichtian.

Family Abathomphalidae Pessagno, 1967

1982 Abathomphalinae Loeblich \& Tappan: 34. 1988 Abathomphalinae Loeblich \& Tappan: 471.

Diagnosis. Rugoglobigerinacea with umbilical-extraumbilical to spiro-umbilical primary aperture, and with porticus or tegilla.

Emended description. Test trochospiral, chambers globular to compressed, axial periphery rounded, or angular to truncate with or without imperforate peripheral band, sutures radial to curved, depressed to elevated; wall calcareous, perforate, surface with meridionally arranged pustules and costellae on one or both sides; primary aperture umbilical-extraumbilical to spiro-umbilical with porticus at least in the early stage, later may have tegilla.

Range. Latest Albian-Maastrichtian.
Genus Abathomphalus Bolli, Loeblich \& Tappan, 1957

(Pl. 1, figs 10-12)

1957 Abathomphalus Bolli, Loeblich \& Tappan: 43.

Type species. Globotruncana mayaroensis Bolli, 1951, p. 198.

Diagnosis. Abathomphalidae with compressed later chambers, primary aperture with porticus in the early stage, later with tegillum.

Description. Test in a low to flat trochospiral coil, umbilicate, umbilicus small, chambers petaloid, sutures curved and oblique, depressed to thickened and nodose on the spiral side, depressed and radial on the umbilical side, axial periphery angular to truncate, bicarinate, the two variously spaced keels bordering an imperforate carinal band, keel on the umbilical side may be reduced to a row of short transverse costellae; wall calcareous, perforate, surface with pustules and short costellae in concentric alignment on the spiral side and radial on the umbilical side; primary aperture interiormarginal, umbilical-extraumbilical, and with a porticus, portici of sucecessive chambers coalescing in the early stage, later in the adult stage joined only at few points to form tegilla having distal accessory apertures.

Range. Late Maastrichtian.

\section{Genus Kassabella El-Nakhal, 1984}

(Pl. 2, figs 1-4)

1984 Kassabella El-Nakhal: 140.

Type species. Loeblichella carteri Kassab, 1976, p. 217.

Diagnosis. Abathomphalidae with globular to slightly compressed chambers, and an aperture with tegillum.

Emended description. Test coiled in a low trochospire, chambers globular to slightly compressed, umbilicate, umbilicus wide, axial periphery rounded to angled with no indication of keel or poreless margin, sutures radial, depressed on both sides, umbilicus shallow wide, primary aperture interiomarginal, umbilical-extraumbilical to spiro-umbilical covered by tegilla, surface rugose, covered with meridionally arranged pustules and costellae on both sides.

Remarks. In his original description of Kassabella, El-Nakhal (1984) mentioned that the genus has sutural supplementary apertures on the spiral side, and the primary aperture is bordered by a well-developed lip. Loeblich \& Tappan (1988) questioned the presence of true supplementary apertures and the well-developed lip. Furthermore, they indicated that the umbilicus appears to show the remnants of a tegillum. Loeblich \& Tappan's (1988) notes are confirmed and accepted in the present study. The 'sutural supplementary apertures' appearing on the spiral side (Pl. 2, fig. 1) are considered to be relict apertures or vestiges of the spiro-umbilical primary aperture left uncovered by younger chambers, with limited taxonomic importance (Douglas, 1969; Longoria; 1974, Blow, 1979). Also, an illustration of a better-preserved specimen shows that the primary aperture has a tegillum rather than a porticus (Pl. 2, fig. 4). Consequently, the description of Kassabella is emended 


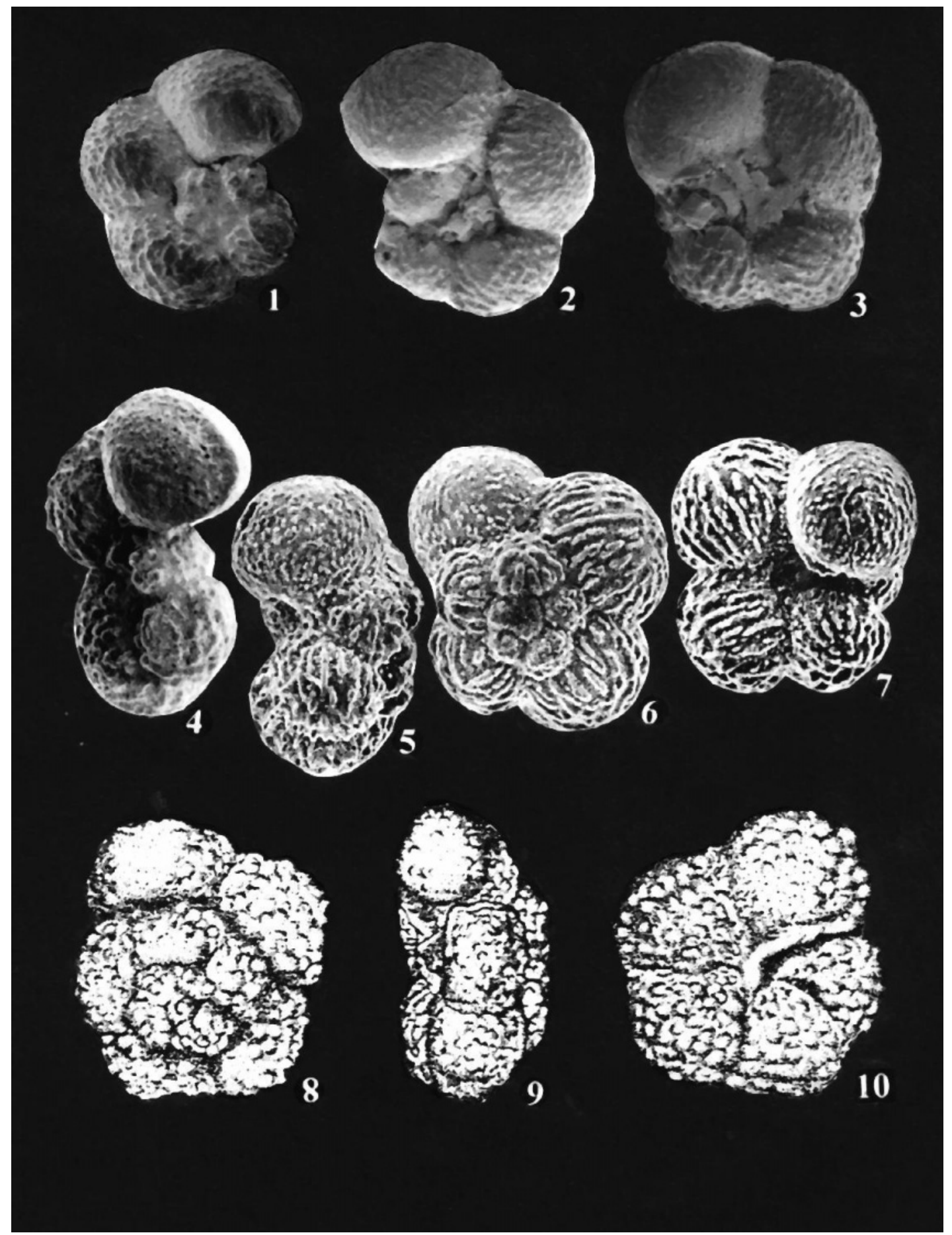

Explanation of Plate 2

Figs 1-4. Kassabella carteri (Kassab), upper-middle Maastrichtian, northern Iraq (from Kassab, 1976): 1, spiral view showing relict 'apertures' $\times 174 ; 2$, umbilical view showing remnants of tegillum $\times 153 ; \mathbf{3}$, umbilical view showing better preserved tegillum $\times 215 ; \mathbf{4}$, oblique edge view $\times 215$. Figs 5-7. Meridionalla pilula (Belford) Upper Cretaceous, Westrn Australia, $\times 200$ (from Belford, 1983): 5, spiral view; 6, edge view; 7, umbilical view. Figs 8-10. Badriella mouradi n. sp., holotype (=juvenile hypotype of Praeglobotruncana loeblichae Douglas, 1969), redrawing of the juvenile hypotype of $P$. loeblichae Douglas, Coniacian, northern California, USA, $\times 180$ : 8, spiral view; 9, edge view; 10, umbilical view.

to accommodate the meridionally costellate species having an umbilical-extraumbilical to spiro-umbilical primary aperture with tegilla, globular to ovate chambers, and lacking sutural supplementary apertures.
Loeblich \& Tappan (1988) considered Kassabella to be a junior synonym of Archaeoglobigerina. However, Kassabella is distinguished from Archaeoglobigerina by its meridionally arranged surface rugosity which is lacking in the latter genus. 
Also, the umbilical-extraumbilical to spiro-umbilical primary aperture distinguishes Kassabella from Rugoglobigerina which has an umbilical primary aperture.

Range. Late Campanian-late Maastrichtian.

Genus Meridionalla El-Nakhal, 1982

(Pl. 2, figs 5-7)

1982 Meridionalla El-Nakhal: 34.

Type species. Hedbergella murphyi Marianos \& Zingula, 1966, p. 336.

1983 Costellagerina Petters, El-Nakhal \& Cifelli: 248.

Type species. Rugoglobigerina (R.) bulbosa Belford 1960, p. 94.

Diagnosis. Abathomphalidae with globular chambers and an aperture borderd by a porticus.

Description. Test low to medium trochospiral, umbilicate, umbilicus commonly narrow, axial periphery rounded with no indication of keel or poreless margin, chambers globular to ovate, equatorial periphery lobulate, sutures depressed, radial straight to curved; wall calcareous perforate radial in structure, surface rugose with meridionally arranged pustules and costellae on both sides; primary aperture interiomarginal, umbilical-extraumbilical bordered by a porticus.

Remarks. El-Nakhal (1999), indicated that both Meridionalla El-Nakhal, 1982 and Costellagerina Petters et al., 1983 include meridionally costellate species that have globular chambers, and an umbilical-extraumbilical primary aperture with porticus. Consequently, he concluded that they are congeneric. As Meridionalla has the date priority over Costellagerina, El-Nakhal (1999) considered it to be the senior synonym.

Recently, Petrizzo \& Premoli Silva (2000) examined the original drawings of the holotypes of the type species of both genera. They observed that the type species of the genus Meridionalla (i.e. Hedbergella murphyi Marianos \& Zingula, 1966) does not possess the meridionally orientated costellae, the main feature on which the genus Meridionalla was erected, except for rare apparently aligned pustules on the umbilical side of the last chamber. Petrizzo \& Premoli Silva (2000) added that even those rare pustules were not detected in recently taken scanning electron micrographs of the holotype. They considered this as a confirmation of the absence of the meridionallyarranged costellae in the holotype of $H$. murphyi. They have, therefore, interpreted the pustules observed in the original drawings as being drawing artefacts. On the other hand, the original drawings of the type species of the genus Costellagerina (i.e. Rugoglobigerina bulbosa Belford, 1960) show a clear meridionally-arranged rugosity. Consequently, they concluded that Costellagerina is the appropriate genus, while the genus Meridionalla is inappropriate, considering it as a junior synonym of Hedbergella. However, the re-examination of the original drawings of the holotype of $H$. murphyi Marianos \& Zingula, 1966, shows that the meridional rugosity occurs on at least the first chamber of the last whorl of the spiral side, and on the first chamber and the last three chambers of the umbilical side, though the meridional rugosity seems to be poorly developed. The occurrence of the meridional rugosity on the holotype of H. murphyi, is confirmed by Douglas (1969), who labelled as Hedbergella murphyi, specimens exhibiting a surface-texture with clear costellae aligned in preferred orientation particularly on the umbilical side where the pustules and pustule ridges radiate from the umbilicus (Douglas, 1969, pl. 5, fig. 8, reproduced in Petrizzo \& Premoli Silva, 2000, pl. 1, fig. 4).

Clearness and detectability of the meridionally arranged costellae depend on the degree of its development and on the position of the costellate chambers relative to the light source. In many cases, it is easy to observe the meridional rugosity when examined by the light microscope (sometimes you need to move the stage left and right to make the rugosity more clear), but when examined by the scanning electron microscope, it becomes undetectable. An example of this case is shown in Petrizzo \& Premoli Silva (pl. 2, 2000). In this plate, the meridionally arranged rugosity is obseved on only the 4th chamber of the last whorl of the spiral view (fig. 2a), despite that it is believed that the meridional rugosity is found on other chambers of the photographed test. Therefore, the rugosity which Petrizzo \& Permoli Silva (2000) referred to as rare apparently aligned pustules observed on the umbilical side of the last chamber of the holotype, is actual meridionally arranged rugosity and not a drawing artefact as those two authors interpreted.

In conclusion, the genus Meridionalla El-Nakhal, 1982, is the valid genus and it remains the senior synonym, whereas Costellagerina Petters et al., 1983 is invalid and should be considered to be a junior synonym.

Range. The range of Meridionalla and its junior synonym Costellagerina was considered to be Cenomanian-Campanian (El-Nakhal, 1982; Petters et al., 1983; Loeblich \& Tappan, 1988). However, as Meridionalla lybica was recorded from strata of latest Albian to Middle Campanian age (Premoli Silva \& Sliter, 1994), the range of the present genus is modified to latest Albian-Campanian.

Badriella n. gen.

(Pl. 2, figs 8-10)

Type species. Badriella mouradi n. sp. (= hypotype of Praeglobotruncana loeblichae Douglas, 1969, p. 170, pl. 5, fig. 6).

Diagnosis. Abathomphalidae with compressed later chambers and an aperture bordered by a porticus.

Description. Test free, trochospiral, umbilicate, axial periphery subangular with nonporous carinal band, equatorial periphery lobulate, chambers compressed, sutures curved on spiral side radial on umbilical side, flush to slightly depressed, surface rugose covered with meridionally arranged rugosities on the umbilical side; aperture an interiomarginal, umbilicalextraumbilical arch, bordered by a narrow lip, supplementary apertures absent; wall calcareous, hyaline, finely perforate, radial in structure.

Remarks. In the discussion of his new species Praeglobotruncana loeblichae, Douglas (1969) indicated that meridionally arranged rugosities displayed by that species are features suggestive of the genus Rugoglobigerina, but its apertural characteristics 
include relationships to the rotaliporids. He added that $P$. loeblichae exhibits the diagnostic features of the genus Praeglobotruncana Bermudez, but its spinose surface sets it aside from the other species of Praeglobotruncana. These remarks substantiate the necessity of erection of the present new genus to accommodate the forms exhibiting characters related to the two genera Rugoglobigerina and Praeglobotruncana.

This new genus is named in honour of the author's wife Mrs Abla M. El-Badri.

Range. Forms which can be included within the present new genus include Praeglobotruncana loeblichae Douglas, 1969, Praeglobotruncana helvetica (Bolli) of Weidich (1984), and Praeglobotruncana praehelvetica (Trujillo) of Weidich (1984). $P$. loeblichae was recorded from the upper Turonian-lower Coniacian of California and Alaska (Douglas, 1969), whereas $P$. helvetica and $P$. praehelvetica of Weidich are recorded from the Turonian and the middle Cenomanian-Turonian of the Bavarian Alps, respectively (Weidich, 1984). Accordingly, the range of Badriella n. gen. is considered to be middle Cenomanian-early Coniacian.

\section{Badriella mouradi $\mathrm{n} . \mathrm{sp}$.}

(Pl. 2, figs 8-10)

1969 (pars) Praeglobotruncana loeblichae Douglas: 170, pl. 5, fig. 6; non fig. 7.

Diagnosis. Badriella with compressed chambers, two faint keels, and meridionally arranged rugosity on the umbilical side.

Description. (Described holotype Pl. 2, figs 8-10.) Test free, low trochospiral, umbilicate, spiral side slightly convex, umbilical side slightly concave, equatorial periphery lobulate, axial periphery truncate with two faint keels on the last chambers, chambers compressed, increasing gradually in size as added, last whorl with five chambers, sutures depressed, radial straight to slightly curved on both sides; aperture a low interiomarginal umbilical-extraumbilical arch, bordered by a narrow lip, umbilicus narrow, shallow; surface spinose to rugose, surface rugosity tangentially arranged on spiral side, and meridionally arranged on umbilical side; wall calcareous, hyaline, radial in structure, perforate.

Remarks. This new species was originally figured by Douglas (1969) as a juvenile hypotype of Praeglobotruncana loeblichae Douglas. This form, however, lacks the broadly truncate axial periphery, the well developed twin keels and the wide umbilicus, which characterize the holotype of $P$. loeblichae. Also, it has a better developed meridional rugosity on the umbilical side than the figured holotype. These morphological differences distinguish the hypotype from the holotype, and suggests that they must be separated. Similarly, Caron (1981) recognized the differences between the two types of $P$. loeblichae, considered them as two distinct species, and included the juvenile form in the synonomy of her new species Falsotruncana douglasi. As the juvenile hypotype has meridionally aligned rugosity on the umbilical side, whereas Caron's form lacks this type of ornamentation, it is here treated separately, considered as a distinct species, and given a new name.
This species is named in honour of Prof. Dr Mouradi I. Youssef, of the Department of Geology, Ain Shams University, Cairo, Egypt, in recognition of his contribution to the field of micropaleontology.

Locality. The holotype is from the Sites Formation (Loc. 249), Colusa County, California (cf. Douglas, 1969).

Dimensions of holotype. Maximum diameter: $0.37 \mathrm{~mm}$, thickness: $0.17 \mathrm{~mm}$. (cf. Douglas, 1969).

Range. Late Turonian-Early Coniacian (the upper part of Praeglobotruncana helvetica Zone-Lower part of Globotruncana cachensis Zone) (cf. Douglas, 1969).

Depository. The holotype (= hypotype of Praeglobotruncana loeblichae Douglas, pl. 5, fig. 6) is on deposit in the Helen Tappan collection of Micropaleontology, Department of Geology, University of California, Los Angeles (UCLA 47041) (cf. Douglas, 1969).

\section{SUMMARY AND CONCLUSIONS}

The meridionally arranged rugosity is a genetically controlled character whose occurrence is restricted to the Cretaceous planktonic foraminifera. It is regarded as a fundamental criterion for taxa at the superfamily level. Forms displaying this type of ornamentation are included within the superfamily Rugoglobigerinacea. On the basis of the apertural characteristics of the included genera, this superfamily is divided into two families: the Rugoglobigerinidae and the Abathomphalidae. The former family includes the genera Rugoglobigerina Brönnimann, Trinitella Brönnimann, and Plummerita Brönnimann, which have an umbilical primary aperture. The latter family includes the genera: Kassabella El-Nakhal, Abathomphalus Bolli, Loeblich \& Tappan, Meridionalla El-Nakhal and Badriella n. gen., which have an umbilical-extraumbilial to spiro-umbilical primary aperture. Badriella is introduced as a new genus with $B$. mouradi n. sp. (= hypotype of Praeglobotruncana loeblichae Douglas) as a type species to include the abathomphalids having compressed chambers, and umbilical-extraumbilical primary aperture with porticus.

The genus Meridionalla El-Nakhal is the earliest member of this group. It appeared during the latest Albian and continued up to the Late Campanian. It is considered the basic stock from which all the meridionally costellate planktonic foraminifera evolved (Fig. 1). Meridionalla most likely evolved from a hedbergelline ancestor during the latest Albian via the development of the meridionally arranged rugosity. Like most other Cretaceous planktonic foraminifera, the Rugoglobigeribacea completely disappeared at the end of the Late Cretaceous.

\section{ACKNOWLEDGEMENTS}

I am greatly indebted to Dr I. Kassab of the Directorate of the Geological Survey and Mineral Investigation of Iraq and Dr J. Salaj of the Geological Institute Dionyz Stur, Bratislava, who kindly provided me with the photographs of Loeblichella carteri, and Plummerita hantkeninoides costata, respectively. Sincere thanks are also due to Dr P. Tubbs of the International Commission on Zoological Nomenclature, for his fruitful e-mail 
discussion and comments on the relation between the two genera Meridionalla and Costellagerina. I am very grateful to Prof. Dr M. Caron of the University of Fribourg, Switzerland, and Dr M. Petrizzo of the Dipartimento di Scienze della Terra, Universita degli Studi di Milano, Italy, for providing me with some of their very useful publications. Also, I would like to thank the two anonymous reviewers for their very useful comments and suggestions.

\section{Manuscript received 10 April 2000 Manuscript accepted 15 November 2001}

\section{REFERENCES}

Belford, D. 1960. Upper Cretaceous foraminifera from the Toolonga Calicilutite and Gingin Chalk, Western Australia. Bureau of Mineral Resources, Australia, Bulletin, 57: 1-198.

Belford, D. 1983. Note on costellate planktonic foraminifera, and the generic designation of Late Cretaceous forms from Western Australia. In: Paleontological papers. Bureau of Mineral Resources, Australia, Bulletin, 217: 1-9.

Blow, W. 1979. The Cainozoic globigerinida, 1-3, E. J. Brill, Leiden, $1-1413$.

Bolli, H. 1951. The genus Globotnincana in Trinidad, B.W.I. Journal of Paleontology, 25: 187-199.

Bolli, H., Loeblich, A.R.Jr \& Tappan, H. 1957. Planktonic foraminiferal families Hantkeninidae, Orbulinidea, Globorotalidae and Globotruncanidae. US National Museum Bulletin, 215: 3-50.

Brönnimann, P. 1952. Globigerinidae from the Upper Cretaceous (Cenomanian Maestrichtian) of Trinidad, B.W.I. Bulletin of American Paleontology, 34: 1-70.

Caron, M. 1978. Cretaceous planktonic foraminifers from DSDP Leg 40, southern Atlantic Ocean. In Bolli, H. \& Ryan, W. (Eds), Initial Reports of Deep Sea Drilling Project, 40: US Government Printing Office, Washington, D.C., 651-678.

Caron, M. 1981. Un nouveau genre de formanifere planctonique du Crétacé: Falsotruncana nov. gen. Eclogae Geologicae Helvetiae, 74: 65-73.

Caron, M. \& Homewood, P. 1982/1983. Evolution of early planktonic foraminifers. Marine Micropaleontology, 7: 453-462.

Douglas, R. 1969. Upper Cretaceous planktonic foraminifera in northern California, part 1-systematics. Micropaleontology, 15: 151-209.

El-Nakhal, H. 1973. Stratigraphy and planktonic Foraminiferida of the Late Cretaceous-Early Paleogene succession in Kuwait. PhD thesis, Kuwait University, Kuwait, 1-566.

El-Nakhal, H. 1982. Meridionalla, a new foraminiferal genus (Globigerinacea, Late Cretaceous). Research Journal of Aleppo University, 4: 33-35.

El-Nakhal, H. 1984. Kassabella, a new Late Cretaceous planktonic foraminiferal genus with meridional rugosity. Journal of Foraminiferal Research, 14: 140-141.

El-Nakhal, H. 1999. The relation between the Late Cretaceous foraminiferal genera Meridionalla EI-Nakhal (1982) and Costellagerina Petters and others (1983). Journal of Foraminiferal Research, 29: 85.

El-Nakhal, H. \& El-Naggar, Z. 1983/1984. On the occurrence of the foraminiferal genus Rugoglobigerina in the Late Cretaceous succession of Kuwait. Journal of the Geological Society of Iraq, 16: 149-183.

Kassab, I. 1976. Some Upper Cretaceous planktonic formaninferal genera from northern Iraq. Micropaleontology, 22: 215-238.
Loeblich, A.R. Jr \& Tappan, H. 1964. Sarcodina, chiefly 'Thecamoebians' and Foraminiferida. In Moore, R.C. (Ed.), Treatise on Invertebrate Paleontology, Protista 2, pt. C, 2, Kansas University Press $1-900$.

Loeblich, A.R. Jr \& Tappan, H. 1982. Classification of the Foraminiferida. In Broadhead, T.W. (Ed.), Foraminifera, notes for a course organized by M. A. Buzas, and B. K. Sen Gupta. Studies in Geology, 6, University of Tennessee, Department Geological Sciences 2236.

Loeblich, A.R. Jr \& Tappan, H. 1988. Foraminiferal genera and their classification. Van Nostrand Reinhold Company, New York, $1-970$.

Longoria, J. 1974. Stratigraphic, morphologic, and taxonomic studies of Aptian planktonic foraminifera. Revista Espanola de Micropaleontologia, Numero Extraordinario, 1-107.

Longoria, J. \& Gamper, M. 1975. The evolution and classification of Cretaceous planktonic foraminifera, part 1: the superfamily Hedbergelloidea. Revista Española de Micropaleontologia, Numero Extraordinario, 61-96.

Longoria, J. \& Gamper, M. 1984. Subfamily Helvetiellinae, a new group of Late Cretaceous (Maastrichtian) planktonic foraminifera. Micropaleontology, 30: 171-179.

Marianos, A. \& Zingula, R. 1966. Cretaceous planktonic foraminifera from Dry Creek Tehama County, California. Journal of Paleontology, 40: $328-342$

Olsson, R. 1964. Late Cretaceous planktonic foraminifera from New Jersey and Delware. Micropaleontology, 10: 157-188.

Pessagno, E.A. Jr 1967. Upper Cretaceous planktonic foraminifera from the Western Gulf coastal Plain. Palaeontographica Americana, 5: 249-445.

Petrizzo, M. \& Premoli Silva, I. 2000. Upper Cretaceous meridionally costellate hedbergellids: the genus Meridionalla El-Nakhal, 1982 vs. the genus Costellagerina Petters, El-Nakhal, and Cifelli, 1983. Journal of Foraminiferal Research, 30: 306-309.

Petters, S., El-Nakhal, H. \& Cifelli, R. 1983. Costellagerina, a new Late Cretaceous globigerine foraminiferal genus. Journal of Foraminiferal Research, 13: 247-251.

Plummer, H. 1927. Foraminifera of the Midway Formation in Texas. University of Texas Bulletin, 2644: 1-206.

Premoli Silva, I. \& Sliter, W. 1994. Cretaceous planktonic foraminiferal biostratigraphy and evolutionary trends from the Bottaccione section, Gubbio, Italy. Paleontographica Italica, 82 (1995): 1-89.

Robaszynski, F. \& Caron, M. 1995. Foraminifers planktoniques du Cretace: commentaire de la zonation Europe-Mediterranee. Bulletin Société Géologique de France, 166: 681-692.

Saint-Marc, P. 1973. Presence de Hedbergella à 'costellae' dans le Cenomnien moyen du Liban. Journal of Foraminiferal Research, 3: $7-12$.

Saito, T. \& Van Don, J. 1974. Oxygen and carbon isotope measurements of Late Cretaceous and Early Tertiary foraminifera. Micropaleontology, 20: 152-177.

Salaj, J. \& Solakius, N. 1984. The genus Kassabiana Salaj, 1983, from the uppermost Maastrichtian of northern Tunisia. Canadian Journal of Earth Sciences, 21: 1199-1204.

Subbotina, N. 1959. In Rauzer Chernoussova, D. \& Fursenko, A. (Eds), Osnovy Paleontologii Obshchaya chast, Prosteyshie (Principles of Paleontology, part 1, Protozoa) 1, Akademiya Nauk SSSR, Moscow, $1-368$.

Weidich, K. 1984. Feinstratigraphie, Taxonomie planktonischer Foraminiferen und Palokologie der Foraminiferengesamtfauna der kalkalpinen tieferen Oberkreide (Untercenoman-Untercampan) der Bayerischen Alp. Bayerische Akademie der Wissenschaften Mathematisch-Naturwissenschaftliche Klasse Abhandlungen Neue Folge, 162: 1-151. 